\title{
Is aqueous leaf extract of guava spermatotoxic in rat?
}

\author{
Ekaluo $^{1}$, U.B., Erem ${ }^{1}$, F. A., Omeje ${ }^{2}$, I.S., Ikpeme ${ }^{1}$, E. V., Ibiang ${ }^{1}$, Y.B. and \\ Ekanem. ${ }^{3}$ B.E. \\ ${ }^{1}$ Department of Genetics and Biotechnology, University of Calabar, Calabar, Nigeria. \\ ${ }^{2}$ Department of Animal Science. Delta State University, Asaba, Nigeria. \\ ${ }^{3}$ Department of Science and Technology, Akwa Ibom State Polytechnic, Ikot Osurua, Nigeria.
}

\begin{abstract}
Spermatotoxicity of aqueous leaf extract of guava (P. guajava) was accessed on the weight of testes and epididymes, sperm parameters and fertility in albino rat as a model. The male rats were divided into four groups of six rats each. The rats were administered with guava leaf extract at $0,100,200$ and $300 \mathrm{mg} / \mathrm{kg} \mathrm{BW}$ respectively for 70 days. The results showed dose-dependent significant $(P<0.01)$ increases in weight of testes and epididymes, sperm count, sperm motility and sperm viability. Dose-dependent increases were also observed in conception rate of female rats sired by treated male rats from 41.67 to $83.33 \%$, as well as the number of offspring from 17 to 42 respectively. The profound positive effects of aqueous leaf extract of guava on sperm parameters amongst others are not indications of spermatotoxicity.
\end{abstract}

Key words: Guava, toxicity, sperm parameters, conception rate, fertility,

\section{Introduction}

Plants have provided the basis for traditional treatment of different types of disease and still offers enormous potential source of new chemotherapeutic agents. According World Health Organization [1], more than $80 \%$ of the world's population still relies on herbal medicines as their primary source of health care [2]. The use of herbs is very common in the developing countries, particularly in rural settings. However, during the last decade, an increase in the use of plants has been observed in the metropolitan areas of developed countries [3]. In Nigeria, medicinal plants are being used by traditional healers either singly or in combination [4].

Toxicity studies of Psidium guajava in mice and other animal models as well as controlled human studies show that fruit, leaf and root are safe and without side effect [5].

In folk medicine, especially in some traditional African localities, decoctions from Psidium guajava leaves are employed as aphrodisiac and in the treatment of sexual dysfunctions such as erectile and potency problems in males. However, there is paucity of written evidence to support this claim [6].

Therefore the present study was designed to evaluate the effect of aqueous leaf extract of guava on weight of testes and epididymes, sperm parameters, conception rate and fertility of a male albino rats as model for ascertaining its spermatotoxicity.

\subsection{Plant materials}

\section{Materials And Methods}

Guava leaves were collected from the botanical garden of the Botany Department, University of Calabar, Calabar. The leaves were sun-dried and pulverized into fine powder.

\subsection{Experimental animals}

Ninety six healthy adult albino rats ( 24 males and 72 females) of 60 to 70 days old were used. The males were divided into 4 groups of 6 animals each in a Complete Randomize Design (CRD) and housed in conventional wire mesh cages.

\subsection{Experimental procedure}

The rats were administered with aqueous leaf extract of guava at $0,100,200$ and $300 \mathrm{mg} / \mathrm{kg} \mathrm{BW}$ respectively for 70 days. On the sixty sixth day of treatment, both the treated and control males were allowed to sire the untreated females in a ratio of 1 male: 3 females for 4 days. The experimental animals were allowed free access to water and commercial feed throughout the period of the experiment. Generally, the study was conducted in accordance with the recommendation from the declarations of Helsinki on guiding principles in care and use of animals. The males were anesthetized in chloroform vapour. The testes and epididymes were dissected out, weighed immediately and the epididymes were processed for epididymal sperm analysis [7, 8]. 


\subsection{Collection of data and analysis}

Data were analyzed statistically using the Completely Randomize Design (CRD) and means with significant differences were separated using least significant difference (LSD) test.

\section{Results}

The results obtained for the sperm parameters, weights of testes and epididymes are summarized in Table 1. The result for testes and epididymes revealed dose-dependent increases in weights of reproductive organs with significant increase $(\mathrm{P}<0.01)$ in treatment groups $\mathrm{C}(200 \mathrm{mg} / \mathrm{kg} \mathrm{BW})$ and $\mathrm{D}(300 \mathrm{mg} / \mathrm{kg} \mathrm{BW})$ for testes and group D $(300 \mathrm{mg} / \mathrm{kg} \mathrm{BW})$ for epididymes when compared with control values. However, there was significant difference $(\mathrm{P}<0.01)$ in sperm motility and sperm count for treatment group $\mathrm{D}(300 \mathrm{mg} / \mathrm{kg} \mathrm{BW})$ when compared with their respective control values. Fig. 1 shows the increase in the conception rate which ranged from $50 \%$ to $83.33 \%$, as well as the number of offspring increasing from 17 to 42 ; which were directly proportional to sperm viability and sperm count.

Table 1: Effect of aqueous leaf extract of guava on sperm parameters, weight of the testes and epididymes in male rats.

\begin{tabular}{lrrrrc}
\hline Parameters & \multicolumn{5}{c}{ Guava extract (mg/kg BW) } \\
& Control (0) & \multicolumn{1}{c}{100} & \multicolumn{1}{c}{200} & \multicolumn{1}{c}{300} & LSD value \\
\hline Testes (g) & $1.29^{\mathrm{a}} \pm 0.05$ & $1.48^{\mathrm{a}} \pm 0.15$ & $1.79^{\mathrm{b}} \pm 0.09$ & $1.94^{\mathrm{c}} \pm 0.06$ & 0.32 \\
Epididymes (g) & $0.33^{\mathrm{a}} \pm 0.02$ & $0.34^{\mathrm{a}} \pm 0.01$ & $0.40^{\mathrm{a}} \pm 0.01$ & $0.42^{\mathrm{b}} \pm 0.02$ & 0.08 \\
pH of semen & $7.20^{\mathrm{a}} \pm 0.06$ & $7.24^{\mathrm{a}} \pm 0.04$ & $7.28^{\mathrm{a}} \pm 0.00$ & $7.24^{\mathrm{a}} \pm 0.04$ & - \\
Sperm viability (\%) & $81.20^{\mathrm{a}} \pm 3.17$ & $86.51^{\mathrm{a}} \pm 2.46$ & $88.11^{\mathrm{a}} \pm 2.63$ & $91.95^{\mathrm{a}} \pm 1.11$ & - \\
Sperm motility (\%) & $72.25^{\mathrm{a}} \pm 4.25$ & $74.06^{\mathrm{a}} \pm 2.78$ & $82.04^{\mathrm{a}} \pm 1.63$ & $88.60^{\mathrm{b}} \pm 2.77$ & 11.22 \\
Sperm count (x 10\% $/ \mathrm{ml})$ & $6.90^{\mathrm{d}} \pm 0.15$ & $7.25^{\mathrm{a}} \pm 0.51$ & $8.00^{\mathrm{a}} \pm 0.26$ & $9.10^{\mathrm{b}} \pm 0.01$ & 2.10 \\
Sperm head abnormality (\%) & $3.75^{\mathrm{a}} \pm 0.40$ & $3.53^{\mathrm{a}} \pm 0.30$ & $3.60^{\mathrm{a}} \pm 0.23$ & $3.93^{\mathrm{a}} \pm 0.20$ & - \\
\hline
\end{tabular}

abc [Values across the table with similar superscript are not significantly different at 5\% based on ANOVA]

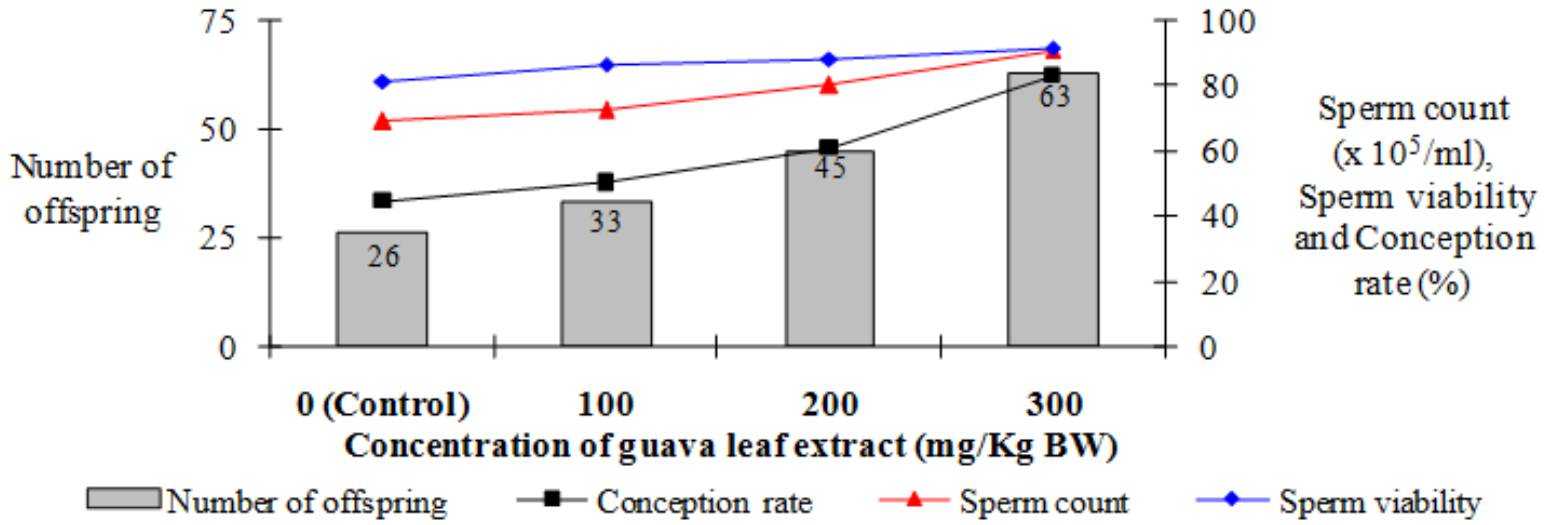

Figure 1: Effect of aqueous leaf extract of guava on number of offspring, sperm count, sperm viability and conception rate in rats

\section{Discussion}

The increase in the weight of the testes and epididymes also correspond with the increase in the levels of sperm production in the treated groups. These show that guava leaf extract has the potentials in enhancing male fertility and reproduction, which agrees with the reports of Akinola et al. [9] and Cajuday and Pocsidio [10]; with increasing fertilizing capacity [11] as seen in the increased conception rate and number of offspring.

Guava leaf extract seems to have spermatogenic effects and the dose-dependent increases in sperm count, sperm viability, sperm motility could be attributed to the antioxidants present in the guava leaf [9] and the stimulatory activity of some of the chemical agents on the reproductive functions in male rats [6].

The profound positive effects of aqueous leaf extract of guava on weight of testes and epididymes, sperm parameters, conception rate, number of offspring (fertility) of a male albino rats as model agrees with earlier reports $[6,11,12]$ and confirms that aqueous leaf extract of guava is not spermatotoxic. 


\section{References}

[1] World Health Organization (WHO, 1992). WHO laboratory manual for the examination of human sciences and sperm-cervical mucus interaction: Cambrige University Press.

[2] Pamplona-Roger, G. D. (1999). Encyclopedia of medicinal plants. Madrid: Editorial Safeliz.

[3] Harnack, L. J.; Rydell, S. A. and Stang, J. (2001). Prevalence of the use of herbal products by adult in the Minneapolis / St Paul, Minnesota and metropolitan area. Mayor Clinical Proceeding, 76: 688-694.

[4] Igweh, A. C. and Onabanjo A. O., (1989). Chemotherapeutic effect of Annona senegalensis in T.B. brucei. Annual Tropical and Medical Parasitology, 83:527-534.

[5] Kamath, J.V.; Rahul, N.; Ashok-Kumar, C.K. and Lakshmi S. M. (2008). Psidium guajava: A review. Journal of Green Pharmacology, 2:9-12.

[6] Uboh, F.E.; Edet, E. E.; Eteng, M. U. and Eyong, E. U. (2010). Comparative effect of aqueous extract of P. guajava and ascorbic acid on serum sexhormones levels in male and female rats. Journal of Applied Science and Research, 6(4): 275-279.

[7] Ekaluo, U.B.; Ekpenyong, E.; Ndome, C.B.; Udoh, P.B. and Ikpeme, E.V. (2011). Reproductive toxicity of processed seeds of horse eye bean (Mucuna urens L.) in male rats. International Journal of Recent Scientific Research, 2: 250-253.

[8] Ekaluo, U.B.; Ikpeme, E.V.; Udensi, O.; Markson, A.A.; Madunagu, B.E.; Omosun, G. and Umana, E.J. (2011). Anti-fertility activity of aqueous leaf extract of neem (Azadirachta indica) in male albino rats. World Journal of Medical Pharmaceutical and Biological Sciences, $1: 1-5$.

[9] Akinola, O. B.; Oladosu, O. S. and Dosumu, O. O. (2007). Spermatoprotective activity of the leaf extract of P. guajava Linn. Nigerian Postgraduate Medical Journal, 14(4):273-6

[10] Cajuday, L. A. and Poscidio, G. L. (2010). Effects of Moringa oleifera Lam (Morigaceae) on the reproduction of male mice (Mus musculus). Journal of Medical Plants Research, 4(12):1115-1121.

[11] Londonkar, R. L.; Sharangouda and Patil, S. B. (2009). Antifertility activity and phytochemical studies of Pergularia daemis leaves in male albino rats. Annual Indian Journal Natural Production, 5:45-49.

[12] Gupta, R. S.; Kachawa, J. B. and Chandhary, R. (2004). Anti-fertility effect of methanolic pod extract of Albizzia lebbeck. Asian Journal of Andrology, 6:155-159. 